\title{
CIBORGUES NO CIBERESPAÇO articulações entre potência, tecnologia e apropriação de sentido
}

\author{
Carla Rodrigues ${ }^{1}$
}

\begin{abstract}
Resumo: $O$ objetivo desse artigo é discutir as proposições que George Landow faz sobre hipertextualidade, a partir de um diálogo que estabelece com o pensamento de Jacques Derrida. Procuro demonstrar que, em Landow, o hipertexto aparece como instrumento mais potente para se alcançar o sentido de um texto, numa leitura que reforçaria um ideal de potência supostamente presente na articulação humano-máquina. Tomo como ponto de partida o ciborgue de Donna Haraway para discutir aspectos dessa articulação entre máquina e potência.
\end{abstract}

Palavras-chave: Hipertextualidade. Ciberespaço. Ciborgue. Sujeito

\begin{abstract}
The aim of this paper is to discuss George Landow's propositions on hypertextuality, starting from a dialogue established by Landow with Jacques Derrida's ideas. The paper demonstrates that, in Landow's proposition, hypertext appears as a more powerful tool used to achieve the meaning of a text, an interpretation that could strengthen an ideal of power supposedly present in the human-machine joint. In order to demonstrate that, I present Donna Haraway's cyborg as a starting point for a discussion about aspects of the machine-power joint.
\end{abstract}

Key-words: Hypertextuality, Cyberspace, Cyborg, Subject

As reflexões que proponho aqui entre a visão da tecnologia como potência e as possibilidades de apropriação de sentido terão como fio condutor as proposições de Donna Haraway, para quem o ciborgue é "um tipo de eu desmontado e remontado" (HARAWAY, 1994: 262), embaralhamento de sujeito e objeto. A figura serve aos objetivos desse artigo: tendo como pano de fundo esse personagem homem/máquina, proponho uma reflexão sobre as possibilidades de produção de sentido, numa releitura das ligações que George Landow faz entre hipertextualidade e as teorias pós-estruturalistas, especificamente na maneira como o filósofo Jacques Derrida pensa a questão da linguagem e o que ele chama de referencialidade aberta $^{2}$.

\footnotetext{
${ }^{1}$ Professora agregada do Departamento de Comunicação Social da PUC-Rio e professora do curso de pósgraduação stricto sensu "Filosofias da diferença", também na PUC-Rio. Email: carla@puc-rio.br.

${ }_{2}^{2}$ Estou seguindo o termo utilizado por George Lawdon para se referir a Derrida. A denominação de pósestruturalista foi adotada nos EUA mas não é reconhecida por Derrida e bastante problematizada por seus comentadores, que se referem a pensamento da desconstrução
} 


\section{Ciborgues no ciberespaço}

Com o desenvolvimento da microinformática, nos anos 1970, com a expansão das tecnologias sobre redes, nos anos 1980, com a abertura da internet ao acesso comercial, nos anos 1990, e com a chamada revolução wi-fi, nos anos 2000, a participação da comunicação mediada por computador na vida cotidiana se ampliou e encontra-se em expansão em ambientes hiper-conectados. A associação entre dispositivos móveis e a banda larga sem fio nos coloca diante de um fenômeno inédito: a possibilidade de envio e recebimento de dados em tempo real em qualquer lugar do planeta (LEMOS, 2002). Mais ciborgues do que nunca, o "eu" vem sendo montado, desmontado e remontado em aparelhos tecnológicos, que ora aparecem como instrumentos de potência do que é humano, ora aparecem como contaminação indesejável dessa hibridação, desse embaralhamento das distinções sujeito/objeto e, sobretudo, de ameaça ao humano.

"Um ciborgue é um organismo cibernético híbrido", diz Haraway (1994: 243), pontuando que as máquinas do final do século $\mathrm{XX}$ embaralharam as distinções que se pretendiam nítidas entre natural e artificial, entre corpo e mente, entre humano e técnica. "Meu mito ciborgue se refere a fronteiras violadas", complementa a autora (HARAWAY, 1994: 249).

O ciborgue de Haraway seria a imagem de contaminação entre humano e tecnologia e integra uma ampla literatura que associa ficção científica com o ingresso da tecnologia nas interações sociais, do qual Neuromancer, de Wilson Gibson (1984), é um marco. O ciborgue que navega pelo ciberespaço seria uma ameaça, uma indesejável contaminação entre humano e não-humano. Numa certa perspectiva, o ciborgue apareceria como uma ameaça porque encarnaria o fim ao ideal de pureza do humano. No rastro desse pensamento estão autores que vão criticar a fragmentação do sujeito - nesta abordagem, forçosamente entendido como fenômeno da contemporaneidade e consequiência direta da liquidação do sujeito, crime imputado aos pensadores pós-estruturalistas ou pós-modernos ${ }^{3}$.

\section{A questão do sujeito}

Se é impossível demarcar, delimitar ou mesmo pretender indicar quando, quem ou por onde começa o questionamento da existência do sujeito clássico, essa impossibilidade não é

\footnotetext{
${ }^{3}$ Vale remeter à Nietzsche, que no final do século XIX questionou o ideal de verdade da metafísica e é pensado por autores como Gianni Vattimo como o primeiro dos pós-modernos (VATTIMO, 2002).
} 
decorrência de uma falha metodológica. Trata-se principalmente do fato de que o questionamento da existência do sujeito clássico se dá a partir de uma série de feixes que se entrecruzam, no contexto de pensamentos que, cada um a seu modo, irão apontar para lacunas e falhas sobre as quais o conceito de sujeito clássico havia sido construído. Por esse caminho, se poderia falar, portanto, em desconstrução do sujeito muito antes de Jacques Derrida propor essa palavra, antes também de que Heidegger tenha falado em a destruição da metafísica ${ }^{4}$.

Pensadores como Freud e Nietzsche, por exemplo, mostraram a impossibilidade de sustentar os fundamentos - o subjectum - do conceito clássico de sujeito a partir de alguns fatores, entre os quais estão a descoberta do inconsciente, o questionamento da representação e de sua capacidade de trazer à tona o objeto, e a chamada virada lingüística, a partir da qual a linguagem passa a ser entendida não mais como adequação, mas como resultante de processos nos quais palavras como alteridade e inconsciente vão se infiltrar, provocando rachaduras nas paredes que até então sustentavam o edifício da metafísica ocidental (DUQUE-ESTRADA, 2009, p. 17-43).

Por conta de ter apontado para essas rachaduras, que muitos autores gostariam de ignorar, paira sobre o pensamento pós-moderno - denominação vaga, generalista e imprecisa que pretende reunir sob um mesmo arcabouço de pensamento todos aqueles que, mesmo por caminhos distintos, são críticos da metafísica e de seus fundamentos humanistas - a suspeita de ter desconstruído, destruído ou liquidado o sujeito, acusação que em geral vem acompanhada de um apelo que pretende "trazer de volta" esse sujeito, perdido não desde sempre, mas dado como perdido a partir do momento em que esses pensamentos indicam que a sujeito clássico é uma construção datada, cujo fim próximo Michel Foucault anunciou.

Quando Stuart Hall (2006) apresenta sua distinção para três concepções diferentes de identidade, categoriza três tipos de sujeito: o do Iluminismo, o sujeito sociológico, e o sujeito pós-moderno. No Iluminismo, diz ele, o sujeito foi concebido como um indivíduo centrado, unificado, dotado de razão, consciência e ação. Na sequência, o conceito de sujeito sociológico refletia a complexidade do mundo moderno e reconhecia que o sujeito não era nem autônomo nem auto-suficiente, mas formado por um conjunto de relações. O sujeito relacional, composto por várias identidades, algumas delas até contraditórias, abriria espaço,

\footnotetext{
${ }^{4}$ É da palavra alemã Destruktion que Derrida propõe a sua desconstrução, na esteira do projeto de Heidegger, qual seja, a destruição da metafísica, que busca liberar a filosofia dos conceitos herdados da tradição e, nas palavras de Duque-Estrada, "retorná-los à experiência de pensamento original" (http://www.pucrio.br/editorapucrio/autores/autores_entrevistas_paulo_cesar_duque.html. Acesso em 21 de abril de 2009.
} 
ainda seguindo Hall, ao sujeito pós-moderno, que passa a ser pensado como não tendo uma identidade fixa, essencial ou permanente.

Esse sujeito "descentrado" produz a idéia de identidades que não são unificadas em torno de um "eu" coerente. "Somos confrontados por uma multiplicidade desconcertante e cambiante de identidades possíveis, com cada uma das quais poderíamos nos identificar, pelo menos temporariamente", diz Hall (2006 : 13), amplamente citado no debate sobre a relação entre as tecnologias de comunicação e informação e a suposta fragmentação do sujeito pósmoderno.

Nesse ponto, considero importante retornar à argumentação de Derrida a respeito da questão do sujeito: não é possível encontrar o ponto inicial em que a filosofia teria afirmado a presença de um sujeito. Derrida mostra como são antigas, na tradição, as interrogações a respeito do sujeito. Em Husserl, Derrida dirá que o ego aparece marcado pelo não-ego, um indicativo de afirmação e negação. Paradoxos análogos apareceriam em Descartes, Kant e Hegel, argumento que Derrida usará para propor que se "desomogeinize" a referência a qualquer coisa como o sujeito: "Nunca houve para ninguém O Sujeito, eis o que eu gostaria de começar por dizer. O sujeito é uma fábula" (DERRIDA, 1992: 279). Ainda seguindo Derrida, o sujeito está reinterpretado, deslocado, reinscrito, mas não liquidado, e o pretenso diagnóstico de liquidação do sujeito indicaria a ilusão de uma reabilitação, uma promessa de salvação (DERRIDA, 1992: 270). Como sublinha Paulo Cesar Duque-Estrada:

Independentemente de como se coloca tal exigência [ de retorno ao sujeito ], e até mesmo quando não se sabe ao certo o que dizer quando se fala "é hora de voltar ao sujeito", tal afirmação parece contar com um apelo, com uma força de persuasão cada vez maior (DUQUE-ESTRADA, 2005: 245).

A (re) colocação da questão do sujeito faria parte de um pensamento que insiste em afirmar a existência de um ser-presente e de um significado transcendental que a tudo orienta. É o que este artigo busca "cartografar" em leituras como a que Landow faz de Derrida. Para Landow, ainda que se reconheça uma multiplicidade de sentidos, as tecnologias aparecem como instrumento facilitador para dar conta dessa abertura. Nessa perspectiva, Landow se inscreveria num conjunto de autores para os quais ciborgues e ciberespaço aparecem como potências enfim libertadoras das restrições territoriais e temporais da condição humana, saudando as tecnologias de comunicação e informação e as ciências como redentoras.

É o que se pode identificar, por exemplo, mesmo em autores que gostariam de recusar o determinismo tecnológico, como acontece com Manuel Castells (1999). Para ele, a comunicação mediada por computador é bem-vinda como parte de um processo de 
estruturação em rede das atividades econômicas, políticas, sociais e culturais. As transformações da vida contemporânea seriam resultado das exigências de flexibilidade administrativa da economia, das demandas de liberdade individual e de comunicação aberta, e dos avanços das telecomunicações e da microinformática. $\mathrm{O}$ autor articula essas características com as configurações da internet, que ele define como resultado da união do alto desenvolvimento científico (presente nas universidades norte-americanas), das estruturas militares dos EUA e da cultura libertária dos hackers.

Ainda que não sejam determinadas pela tecnologia, as novas configurações dessa sociedade em rede teriam o poder de nos libertar e liberar das nossas meras características humanas. Castells chama este conjunto de alterações de "sociedade da informação", termo sobre o qual não há consenso ${ }^{5}$, cujas principais características seriam, a partir da lógica de redes, maior abertura e flexibilidade, proporcionadas e facilitadas pelas características da internet, fazendo da tecnologia um tipo de recurso que potencializa essas demandas de flexibilidade, mobilidade e organização em rede ${ }^{6}$.

\section{Landow pensa o hipertexto}

Seja visto como salvação ou derrocada da humanidade, o ciborgue encarnaria o "sujeito" do ciberespaço, onde a comunicação se configura como um sistema rizomático, no qual já não é mais possível identificar o emissor e o receptor, tornando a comunicação um processo ainda mais complexo. O rizoma, tipo de planta aquática sem caule, em que qualquer ponto pode se ligar a qualquer ponto, é uma referência ao termo utilizado por Gilles Deleuze e Felix Guatarri para designar um tipo de sistema que coloca em relação signos e não-signos, não se deixa reduzir nem ao uno nem ao múltiplo, não tem começo nem fim, e é feito "direções movediças".

O rizoma é imagem usada por muitos autores (CASTELLS, LÉVY, LANDOW) para caracterizar a experiência de multiplicidade que seria "estar" no ciberespaço. Nessa multiplicidade, o ciborgue se desmonta e se remonta em configurações que são contingentes e provisórias, expressão do que Jean-François Lyotard (1979) chamou de fim das grandes narrativas. $\mathrm{O}$ ciborgue seria o personagem das pequenas e fragmentadas narrativas, sujeito

\footnotetext{
5 Embora não sejam necessariamente equivalentes, haverá autores, como Daniel Bells, que chamarão esse mesmo conjunto de mudanças de sociedade pós-industrial. Outros autores se referem a termos sobre os quais também não há consenso: condição pós-moderna, pós-modernidade, modernidade tardia e modernidade singular (HARVEY, LYOTARD, GIDDENS, JAMESON).

${ }^{6}$ Para uma discussão sobre a articulação entre capitalismo tardio, modos de produção em rede e incorporação, na cultura, de valores como flexibilidade, adaptação, maleabilidade e desterritorialização, ver Rodrigues, 2010.
} 
pós-moderno em permanente processo de readestramento pelas tecnologias de comunicação e pelas biotecnologias, feito de fronteiras permeáveis, interpretado, reinterpretado, reinscrito e ressignificado.

A hipermídia seria, assim, um grande rizoma que, de link em link, sem centro ou direção, poderia expressar essa interatividade homem-máquina, que aparece como vantagem para os dois lados: o humano, porque mais potencializado pela máquina, e a máquina, porque mais humanizada pelo homem. O mesmo rizoma pode ser usado como imagem para a visão mais crítica ou negativa que enxerga nesse descentramento uma perda de fundamentos, rigor, acesso à verdade, presença a si do sujeito.

À imagem do ciborgue se soma uma nova imagem: a da máquina que guarda as mesmas características do humano. Assim, tanto computadores são comparados a cérebros, quanto o cotidiano é invadido por metáforas em que o cérebro é comparado a HDs e a memória humana é comparada a dos computadores. Nesse contexto, surgem as alegorias do upgrade (SIBILIA, 2002), como se corpos e comportamentos precisassem estar sempre em permanente processo de atualização, atendendo às mesmas exigências impostas aos hardwares e softwares.

Um dos autores que enxerga no virtual e na interatividade o aumento das potencialidades do humano é Pierre Lévy (1998): para ele, a partir do momento em que estão postos em interação permanente através das máquinas, seres humanos desenvolveriam maior potencial de inteligência ${ }^{7}$ e maior colaboração, o que redundaria, de forma mais ou menos auto-evidente, em mais democracia. O ciberespaço pode ser entendido como qualquer ambiente simulado ou virtual, uma espécie de não-lugar que abriga todas as conexões, que se materializariam no que muitos autores saúdam como as tramas abertas da hipertextualidade.

O que discuto é a leitura que Landow faz de autores como Derrida e Roland Barthes. Ao pensar as potencialidades do hipertexto, Landow o faz numa abordagem que propõe a hipertextualidade como ferramenta ainda mais potente para se alcançar os diferentes sentidos de texto. Para discutir essa questão, farei a seguir uma breve apresentação de como Landow pensou o hipertexto e suas articulações com o pensamento de Derrida para depois discutir as articulações de Landow entre hipertextualidade e pós-estruturalismo.

O termo hipertexto surgiu nos anos 1960 e foi proposto por Theodor Nelson, que usou a palavra para designar a escrita/leitura não linear em um sistema de informática. Na sua definição, um hipertexto se apresenta numa estrutura não-sequencial, que se bifurca, e que

\footnotetext{
${ }^{7}$ O autor parte dessa idéia para propor o termo inteligência coletiva (LÉVY, 1998).
} 
permite ao leitor fazer escolhas e que é mais bem lido numa tela interativa (NELSON apud LANDOW, 1995:15).

Ao trabalhar a teoria do hipertexto, Landow apresenta o que ele considera as características do hipertexto: a) intertextualidade: o que já acontece nos livros, como as referências a outros textos, seria, segundo Landow, potencializadas no hipertexto através do link, que daria acesso imediato a outras obras à qual ela faz referência, ou acessar textos explicativos ou críticos acerca de tópicos específicos da obra em questão; b) multivocalidade: Landow acredita que a idéia de multivocalidade se apresentaria no hipertexto como uma combinação das ligações - ou lexias - que constituiriam o trajeto da leitura; c) descentralização: ao contrário do que acontece nos textos impressos, em que uma determinada ordem de leitura é proposta (podendo ou não ser obedecida pelo leitor), o hipertexto ofereceria a possibilidade de movimentos de descentramento e recentramento contínuos; d) rizoma: Landow recorre à metáfora de Deleuze e Guatarri para observar que o rizoma se opõe à idéia de hierarquia, pois é um tipo de estrutura que pode conectar qualquer ponto a qualquer outro ponto, oferecendo muitos começos e muitos fins; e) intratextualidade: o termo se refere às ligações internas estabelecidas entre lexias dentro do mesmo sistema.

Ao propor essas características, Landow dirá que a hipertextualidade seria um sistema intertextual que dá forma à maneira como Derrida e Barthes pensaram a linguagem. Barthes compara o texto literário a redes múltiplas que se entrelaçam, sem que nenhuma possa dominar as outras; nas quais se pode penetrar por diversas entradas, sem que nenhuma possa ser considerada principal; em códigos que se oferecem a perder de vista. Ele falar em lexias, termo com o qual ele designa as múltimas redes que se entrelaçam em um texto. Landow chama a atenção para o uso que Barthes faz de termos como nó, lexia e rede, que também se aplicam ao hipertexto.

Nesse texto ideal, as redes são múltiplas e se entrelaçam, sem que nenhuma possa dominar as outras; esse texto é uma galáxia de significantes, não uma estrutura de significados; não tem início, é reversível; nele penetramos por diversas entradas, sem que nenhuma possa ser considerada principal; os códigos que mobiliza perfilam-se a perder de vista, eles não são dedutíveis (o sentido, nesse texto, nunca é submetido a um princípio de decisão e sim por lance de dados); os sistemas de sentido podem apoderar-se desse texto, absolutamente plural, mas seu número nunca é limitado, sua medida é o infinito da linguagem. (BARTHES, $1992:$ 39, grifo do autor).

Landow afirma que Derrida é quem melhor enfatiza a abertura textual, a intertextualidade e a irrelevância da distinção dentro/fora de um texto, características que, como vimos anteriormente, são apontadas por Landow no hipertexto (LANDOW, 2006 : 53). 
Dirá Landow: "Precisamos abandonar sistemas conceituais fundados em idéias de centro, margem, hierarquia, e linearidade e substitui-los por multilinearidade, nós, links e redes" (LANDOW, 2006: 1).

Nas analogias que propõe entre a hipertextualidade no computador e o pensamento de autores como Barthes e Derrida, Landow argumenta que o "hipertexto promete dar corpo e teste assim aos aspectos dessa teoria, particularmente no que diz respeito à textualidade, narrativa, e o papel ou a função do leitor e do escritor" (LANDOW, 2006 : 2). O autor pontua ainda que a maneira como Derrida descreve a linguagem serve também como descrição para o que ele chama de uma "nova economia de leitura e escrita com a forma eletrônica" (LANDOW, 2006: 53). Dirá Landow:

Derrida reconhece adequadamente que, uma forma nova, mais livre e mais rica do texto, que seja mais verdadeira em relação ao potencial da nossa experiência, talvez até da nossa experiência real não reconhecida/identificada, depende de unidades distintas de leitura (LANDOW, $2006: 53$ ).

Para Landow, Derrida estaria descrevendo um novo tipo de texto, que se materializaria em suportes eletrônicos, potencialidade que os livros não seriam capazes de proporcionar, fazendo do hipertexto em suportes eletrônicos um instrumento que daria concretude à referencialidade aberta pensada por Derrida. Landow e Lévy serão entusiastas da idéia do hipertexto como potência, como forma de materializar essa referencialidade aberta com a qual, a partir da chamada virada lingüística, a teoria literária vai trabalhar.

Em relação a Landow, trago a contribuição de Afonso Albuquerque e Simone Pereira de Sá, autores que também discutem a maneira como Landow pensa o hipertexto:

Sua argumentacão centra-se, portanto, na oposição entre o texto tradicional instituído pela imprensa, que o autor descreve como, de regra, obra "fechada", delimitada pelas margens, contido pelo índice e pela paginação e assinado pela autoridade detentora da "verdade" textual, que sugere ao leitor como ler e entender a obra, de um lado; e de outro o hipertexto que aponta para reconfigurações nos papéis de autor, do leitor e, conseqüentemente, da própria concepção de texto e de leitura, traduzindo desta forma uma "mudança de paradigma" (ALBUQUERQUE\&SÁ, 2000 : 86)..

Seguindo essa leitura, cabe observar que Derrida não associa a idéia de abertura a nenhum tipo de suporte, partindo da idéia de que essa abertura é inerente à qualquer experiência de leitura. Nessa referencialidade pensada por Derrida, o sentido não está previamente dado, e o fato desse sentido não ser apropriável não é um problema de método ou forma de acesso mais adequada ou mais potente, como se verá a seguir. 


\section{Derrida pensa a linguagem}

Recupero aqui brevemente como a crítica de Derrida à maneira como tradição pensou o ideal metafísico da presença a si do sujeito: em Aristóteles, os sons emitidos pela voz estavam diretamente ligados aos estados da alma, enquanto as palavras escritas seriam meros símbolos das palavras emitidas pela voz. Nessa cadeia de representação, a palavra escrita estaria mais distante da presença - e portanto da verdade - do que a palavra falada, que guardaria relação natural com o sentido (DERRIDA, 2004).

Derrida mostra que foi em nome dessa ligação entre sentido e voz que a escrita sempre esteve rebaixada em relação à verdade da palavra falada, esta fundamentada na presença como indicação de verdade. A partir daí, ele questiona a estrutura logo-fono-cêntrica da linguagem, em que sentido e voz sempre estiveram no lugar superior de uma estrutura hierárquica que rebaixou escrita e tudo aquilo que estaria fora do logos. Em contraposição a essa polarização ele vai propor um sistema de diferenças em função do qual o "sentido" se estabelece. E sentido, aqui, não apenas está entre aspas, mas está também e sobretudo como algo que não está previamente dado. Ao questionar essa ligação supostamente natural entre voz e sentido, Derrida abrirá uma espécie de fenda no pensamento filosófico contemporâneo, demonstrando como esse fono-logo-centrismo se confundiria com o ideal de presença presença a si do sujeito, do cogito, da consciência.

Desde o Crátilo de Platão a filosofia se debatia com a questão da "justeza dos nomes" - Sócrates participa de um diálogo em que Hermógenes e Crátilo defendem duas posições antagônicas em relação à linguagem. Para Crátilo, as palavras são adequadas às coisas por "natureza", enquanto para Hermógenes vai defender a idéia de pacto, convenção e consenso. Sócrates critica a teoria convencionalista e adere ao naturalismo, fazendo Crátilo vencer Hermógenes (PLATÃO, 2001) ${ }^{8}$. Quando Saussure propõe que, no signo, a ligação entre significante e significado é uma ligação arbitrária, está se aliando a Hermógenes contra Crátilo, numa questão que vinha sendo perseguida pelos estudiosos da linguagem desde o século XIX.

Segundo a leitura de Eric Blondel (1985, p. 115), Nietzsche também havia apontado para conclusões opostas as de Crátilo, mostrando que a etimologia não provava a naturalidade da linguagem, mas sim o caráter arbitrário, característica que Saussure vai aprofundar. Quando Saussure propõe que, no signo, a ligação entre significante e significado é arbitrária, 
está invertendo a tradição e se aliando a Hermógenes contra Crátilo, num movimento que havia sido iniciado pelos estudiosos da linguagem desde o século XIX. No Curso de Linguística Geral, Saussure pensa a língua não mais como um sistema de conteúdos ou valores, mas como um sistema de “diferenças puras” (DOSSE, 2007, p. 82).

É a partir dessa percepção da língua como um sistema de diferenças que Derrida vai desconstruir o signo saussuriano, pensado não mais como união natural entre uma coisa e seu nome, mas como a ligação entre um conceito e uma imagem acústica (DOSSE, 2007, p. 87). Para Saussure, o signo é ao mesmo tempo marca de presença - do significante - e ausência do significado - , e significante e significado são indissociáveis como "duas faces de uma folha de papel”.

Ao desconstruir a estrutura binária significante/significado tal qual proposta por Saussure, Derrida explora o "caráter arbitrário do signo" apontado por Saussure para ir além do pensamento lingüístico e questionar o caráter indissociável entre significante e significado. Partindo do signo como uma ligação arbitrária, Derrida pensa como arbitrárias as estruturas opositivas da metafísica, como sensível/inteligível, dentro/fora, presença/ausência, masculino/feminino.

Quando afirma que não existe significado, só significantes, Derrida vai desprivilegiar não apenas o significado como o que carregaria a dimensão transcendental do signo, como também desqualificar o signo como portador desta pretensa unidade significante/significado seja ela "natural", como queria a tradição, seja arbitrária, como indicou Saussure. Para Derrida, o significado não é mais transcendente, mas aquilo que se dá dentro de uma cadeia de significantes, num jogo de diferenças a partir do qual Derrida vai pensar a différance. $\mathrm{O}$ filósofo questiona a existência do logos do signo, do significado por trás do significante, demonstrando que os significantes só são compreensíveis a partir de uma cadeia de significantes, num jogo de remetimentos e referências em que um significante depende do seu anterior e do seu posterior para fornecer algum "sentido". "Nada escapa ao movimento do significante e, em última instância, a diferença entre o significado e o significante não é nada", diz o filósofo (2004 : 27).

Geoffrey Bennington utiliza o exemplo do dicionário para demonstrar esse processo. Ele lembra que se procurarmos no dicionário o significado de um significante desconhecido, só encontraremos outros significantes, nunca um significado, num jogo infinito que nos que nos leva a só compreender um significante segundo sua posição em relação a outros significantes. A imagem do dicionário se aproximaria de uma experiência de leitura em hipertexto, em que cada significante é um link para o outro significante, numa cadeia infinita 
de remessas. "Há coisas, águas e imagens, uma remessa infinita de uns aos outros, mas sem nascente" (DERRIDA, 2004: 29).

Quando Derrida afirma que não há "significante em si”, não estaria rebaixando o significado para propor uma inversão ou uma estratégia de alçar o significante ao lugar privilegiado que a tradição metafísica conferia ao significado, mas promovendo um deslocamento: da polissemia, que ainda estaria no primado do logocentrismo, na idéia de que há um sentido original, que se espalha de formas diversas, para a disseminação, onde não há mais um querer dizer inicial. É assim que a escritura poderia ser entendida como referencialidade aberta, repetição, deslocamento de presença, não-origem, não-essência. Ao dizer que tudo é escritura, Derrida também considera a palavra falada como escritura, esta também incapaz de transmitir a verdade.

Derrida propõe pensar o "sentido" como aquilo que se dá em função de um sistema de diferenças. E “sentido”, aqui, não apenas está entre aspas, mas está também e, sobretudo, como algo que não é previamente dado. Com isso, Derrida está propondo pensar todo "sentido" como uma construção sempre precária, provisória. Ele não apenas inverte, retirando o "sentido" do significante material para o caráter referencial ou relacional da produção de "sentidos", mas principalmente desloca a pretensão de apropriação de "sentidos". O jogo de remetimentos e referências a que Derrida se refere faz com que um significante dependa do seu anterior e do seu posterior para fornecer algum "sentido". Nesse jogo, cada elemento só adquire identidade em sua diferenciação com os outros elementos do mesmo sistema, o que faz com que cada elemento esteja sempre marcado por aquilo que não é (DUQUEESTRADA, 2002).

Se não há nem significado em si nem significante em si, o que existe é um sistema de diferenças em função do qual o "sentido" se estabelece. Derrida atribui a possibilidade de produção de "sentido" a uma produção constante de diferenças, a um jogo de remetimentos, que podem ser pensadas como os nós, as multicentralidades que Landow identifica na hipertextualidade.

Ao apontar para o rebaixamento do significante, Derrida não está propondo conferir ao suporte o status, o poder, ou a forma mais eficiente de alcançar o sentido.

\section{Os limites do labirinto}

Muitos autores se referem ao hipertexto como um labirinto no qual o usuário traça seu caminho e faz suas próprias escolhas (MACHADO, SANTAELLA, LEÃO). Outros partem 
de uma idéia de teia, tecido, rede. Derrida, por exemplo, fala em rastro e em tecido de signos. Muitos de seus comentadores usam a imagem de trama, que transfere ao leitor a possibilidade de uma livre construção de "sentidos".

Quando faz uma ligação entre hipertextualidade e pós-estruturalismo, Landow se vale de uma parte do pensamento de Derrida, aquela que reconhece na experiência de leitura uma abertura às referências intra e extra-texto. No entanto, a questão abordo nesse artigo é como Landow não abre mão da hipótese de que, por novos caminhos, agora "mais livres”, o leitor possa chegar ao real sentido de um texto. Landow reconhece que não há apenas um sentido, se aproximando mais de uma idéia de polissemia dos textos, e fortemente apoiado numa questionável idéia de liberdade.

Aqui, cabe referir a um exemplo de como a linguagem do hipertexto não necessariamente remete ao ideal de liberdade pensado por Landow. Albuquerque e Sá (2000) mostram como os jogos de computador são estruturados em tramas fechadas nas quais a experiência de "liberdade" não estaria disponível para o usuário.

Longe de basearem em princípios rizomáticos, como aqueles geralmente associados à lógica do hipertexto, os jogos de computador apresentam tramas consideravelmente fechadas, cujo desenrolar depende de o usuário realizar as operações "corretas", tal como definidas pela lógica do software (ALBUQUERQUE\&SÁ, $2000: 83$ ).

Ou seja, mesmo usando as possibilidades da linguagem em hipertexto em suporte eletrônico, os jogos estabelecem roteiros previamente dados, e ao usuário só resta seguir os caminhos traçados. A referencialidade, aqui, não é aberta, mas está previamente definida na estrutura do jogo.

As proposições de liberdade, em Landow, remetem a idéia de polissemia, na qual, para Derrida, ainda haveria a idéia de que há um sentido original, que se espalha de formas diversas. Por isso, cabe pontuar que Derrida promove um deslocamento de polissemia para a disseminação, onde não há mais um querer dizer inicial.

Retomando a imagem do ciborgue, a leitura que Lawdon faz de Derrida reforçaria a idéia de que ciborgues são potencializados pela tecnologia, fazendo da contaminação humano-máquina uma configuração ideal que esse artigo pretende questionar. O ciborgue no ciberespaço seria uma espécie de redenção desse sujeito fragmentado, supostamente liquidado, que encontraria na hipertextualidade caminhos mais eficientes para se apropriar de sentidos, sentidos esses que estariam previamente dados, apenas a espera de caminhos ou mecanismos mais adequados de apropriação. 
Defendo que, na leitura que faz de Derrida, Lawdon toma emprestado apenas uma parte do pensamento do filósofo, ignorando outros aspectos que poderiam levar ao questionamento de que tipo de liberdade se está falando no enaltecemento das estruturas hipertextuais - que, estranhamente, se mantém como estruturas, mesmo quando pensadas com características como abertura. Nessa visão, o hipertexto sobre suporte eletrônico aparece como potência libertadora, como um derivado que nos livraria das limitações humanas.

Com o questionamento que proponho aqui, seria pertinente repensar muito do que se diz sobre "as vantagens e as qualidades do hipertexto" e refletir como essas leituras ainda escondem um ideal de apropriação de sentido, agora dado pelas supostas "maravilhosas possibilidades proporcionadas pela tecnologia”. Entendo essa visão como tributária do ideal de que o ciborgue seria potencializado pela tecnologia, incorporando para si o que as máquinas puderem oferecer de melhor, numa reafirmação ainda mais potente daquilo que Derrida pretendia questionar: não se trata de reconhecer a referencialidade aberta para fazer dela uma forma melhor ou mais eficiente de alcançar todos os possíveis sentidos de um texto, mas de reconhecer a experiência da referencialidade aberta como inerente a qualquer experiência.

O que mais nos inquieta, hoje, é habitar uma midiaesfera complexa, ainda a espera de seus "corajosos cartógrafos", diz Erik Felinto (2007). Como "cartografar" esses territórios sem perder de perspectiva a natureza transitória, contingente e provisória dos objetos de estudo num campo em permanente transformação como o das tecnologias digitais de comunicação? Para usar uma expressão de Paulo Cesar Duque-Estrada (2004) sobre o pensamento de Jacques Derrida, me proponho a trabalhar a partir de uma "desorientação consciente", reconhecendo que toda tentativa de (re)orientação é sempre uma cartografia provisória e incompleta. Trata-se de lidar com essa permanente busca por mapas para novos territórios de conhecimento, reconhecendo que esses mapas são necessariamente contingentes, provisórios e precários, e que labirintos podem ser experiências dessa "desorientação consciente" que não nos remeta a um "sentido" previamente dado.

\section{Referências bibliográficas}

ALBUQUERQUE, Afonso e SÁ, Simone. Hipertextos, jogos de computador e comunicação. Revista FAMECOS, Porto Alegre, $\mathrm{n}^{\circ}$ 13, dezembro 2000.

BARTHES, Roland. S/Z - uma análise da novela Sarrasine de Honoré de Balzac. Nova Fronteira : Rio de Janeiro, 1992. 
BAUMAN, Zigmunt. Medo líquido. Rio de Janeiro : Jorge Zahar Editor, 2008.

Amor líquido - sobre a fragilidade dos laços humanos. Rio de Janeiro : Jorge

Zahar Editor, 2004.

. Modernidade líquida. Rio de Janeiro : Jorge Zahar Editor, 2001.

BENNINGTON, Geoffrey e DERRIDA, Jacques. Jacques Derrida. Rio de Janeiro :

Jorge Zahar Editor, 1996.

BLONDEL, Eric. As aspas de Nietzsche: filologia e genealogia. IN: MARTON, Scarlett (org). Nietzsche hoje? O colóquio de Cerisy. São Paulo : Brasiliense, 1985.

CASTELLS, Manuel. A era da informação: economia, sociedade, cultura. A sociedade em rede, volume I. Paz e Terra : São Paulo, 1999.

. A galáxia da Internet. Jorge Zahar Editora : Rio de Janeiro, 2004.

DERRIDA, Jacques. "Il faut bien manger - entrevista com Jean-Luc Nancy". In:

Point de Suspension - Entretiens. Paris: Galilée, 1992.

. Khôra. Campinas, SP : Papirus, 1995.

. Gramatologia. São Paulo : Editora Perspectiva, 2004.

DELEUZE, Gilles, GUATARRI, Félix. Mil platôs, 5 volumes. Editora 34, São Paulo : 19951997.

DOSSE, François. História do estruturalismo, volumes I e II. Bauru, SP: EDUSC, 2007.

DUQUE-ESTRADA, Elizabeth Muylaert. Devires autobiográficos: a atualidade da escrita de si. Rio de Janeiro : Editora PUC-Rio, Nau Editora, 2009.

.DUQUE-ESTRADA, Paulo Cesar. Ciência e pós-representação: notas sobre Heidegger. Política\&Trabalho. Revista de Ciências Sociais. Número 24, abril de 2006. p. 5971.

"Derrida e a crítica heideggeriana do humanismo". In: NASCIMENTO, Evando

(Org.). Jacques Derrida: pensar a desconstrução. São Paulo: Estação Liberdade, 2005.

. "Alteridade, violência e justiça: trilhas da desconstrução". In: DUQUE-ESTRADA,

Paulo Cesar (Org.). Desconstrução e ética - ecos de Jacques Derrida. Rio de Janeiro: Editora

Puc-Rio e Edições Loyola, 2004.

FELINTO, Erick. 'Materialidades da Comunicação': Por um Novo Lugar da Matéria na

Teoria da Comunicação. Revista Ciberlegenda, número 5, 2001. Disponível em <http://www.uff.br/mestcii/felinto1.htm>. Último acesso: 11 de junho de 2010.

Sem mapas para esses territórios: a cibercultura como campo de conhecimento, IN:

FREIRE, J. e HERSCHMAN, M. Novos rumos para a cultura da mídia. Mauad : Rio de Janeiro, 2007

GIBSON, Willian. Neuromancer. Aleph : São Paulo, 2008. 
GIDDENS, Anthony. As conseqüências da modernidade. UNESP : São Paulo, 1991.

HALL, Stuart. A identidade cultural na pós-modernidade. Rio de Janeiro : DPA Editora, 2006.

HARAWAY, Donna. Um manifesto para os cyborgs: ciência, tecnologia e feminismo socialista na década de 80. IN: HOLLANDA, Heloísa Buarque (org.). Tendências e impasses - o feminismo como crítica da cultura. Rocco : Rio de Janeiro, 1994.

HARVEY, David. Condição pós-moderna - uma pesquisa sobre as origens da mudança cultural. Edições Loyola : São Paulo, 2001. 10a. Edição.

JAMESON, Fredric. Modernidade singular. Civilização Brasileira : Rio de Janeiro, 2005.

LANDOW, George P.. Hipertext 3.0 - Critical theory and new media in a Era of Globalization. The John Hopkins University Press : Maryland, 2006. $3^{\text {a }}$. Edição.

Hipertexto: la convergência de la teoría crítica contemporánea y la tecnologia.

Buenos Aires: Paidós, 1995.

LEÃO, Lúcia. O labirinto da hipermídia: arquitetura e navegação no ciberespaço. Iluminuras : São Paulo, 1999.

LEMOS, André. Comunicação e práticas sociais no espaço urbano: as características dos Dispositivos Híbridos Móveis de Conexão Multirredes (DHMCM). Comunicação, mídia e consumo. Vol. 4, número 10, 2007.

Você está aqui: mídia locativa e teorias "materialidades da comunicação" e "atorrede”. Trabalho apresentado na Compós. Rio de Janeiro : PUC-Rio, 2010.

LÉVY, Pierre. A inteligência coletiva: por uma antropologia do ciberespaço. Edições Loyola : São Paulo, 1998.

LYOTARD, Jean François. A condição pós-moderna. José Olympio Editora : Rio de Janeiro, 2000. $6^{\mathrm{a}}$. Edição.

MACHADO, Arlindo. Hipermídia: o labirinto como metáfora. IN: DOMINGUES, Diana (org.) A arte no século XXI - a humanização das tecnologias. UNESP : São Paulo, 1997.

PLATÃO. Crátilo. Lisboa : Piaget, 2001.

SANTAELLA, Lúcia. Cultura das mídias. Razão Social : São Paulo, 1992.

SAUSSURE, Ferdinand. Curso de lingüística geral. São Paulo : Editora Cultrix, 1995.

SIBILIA, Paula. O homem pós-orgânico - corpo, subjetividade e tecnologias digitais.

Relume-Dumará : Rio de Janeiro, 2002.

VATTIMO, Gianni. O fim da modernidade - niilismo e hermenêutica na cultura pósmoderna. Martins Fontes : São Paulo, 2002. 